\title{
LEVANTAMENTO DE MANIFESTACOES PATOLOGICAS EM FACHADAS DE PATRIMÔNIOS HISTÓRICOS NA CIDADE DE CAXIAS, MARANHÃO
}

\author{
SANTOS, MIKHAEL FERREIRA DA SILVA \\ Mestrando em Engenharia Civil \\ UFPE \\ Pernambuco; Brasil \\ mikhael@ferreiraeng.com
}

\author{
MATOS, WDYELLE ELCINE DE CARVALHO \\ Engenheira Civil \\ UNIFSA \\ Piauí; Brasil \\ wdyellecarvalho@gmail.com
}

\author{
FERREIRA, CLÁUDIO VIDRIH \\ Doutor em Engenharia Civil \\ UNIFACEMA \\ Maranhão; Brasil \\ vidrih@vidrih.com.br
}

\author{
L. GUSTAVO BONORA VIDRIH FERREIRA \\ Arquiteto \\ Via Vidrih e Meio Ambiente \\ São Paulo; Brasil \\ augush2@gmail.com
}

\section{RESUMO}

A cidade de Caxias está localizada na mesorregião leste maranhense, no nordeste brasileiro, sendo o quinto município mais populoso do estado, estando cerca de $360 \mathrm{~km}$ da capital São Luís. Históricamente, caxias é marcada por vários tempos longíquos, gloriósos, sangrentos e poéticos, como se fosse um túnel do tempo. É uma cidade histórica onde as memórias perpassam o cotidiano das pessoas numa relação de grandes marcos que contribuíram para a construção da história do Brasil. Apesar de sua importância histórica como bem material tombado que contribui para o entendimento da identidade cultural da cidade, poucas são as ações que intentam sua preservação, mesmo com o suporte jurídico previsto no artigo 216 da constituição federal, decreto lei 25/1937 e legislações estaduais e municipais. Nesse sentido, esse trabalho tem como objetivo principal realizar um estudo comparativo dos levantamentos de manifestações patológicas incidentes nas fachadas dos principais prédios históricos localizado no centro da cidade de Caxias, estado do Maranhão. A metodologia é baseada em vistorias técnicas por meio de observação direta, com o propósito de realizar registros de informações através de planilha padronizada, o que permitiram tratar os dados. Além de indicar as manifestações patológicas, foram abordadas as possíveis causas e também técnicas de recuperação das edificações analisadas, seguindo as diretrizes propostas pelo Instituto do Patrimônio Histórico e Artístico Nacional (IPHAN). Espera-se que os resultados obtidos possam contribuir para a preservação do patrimônio histórico-cultural do município, permitindo que o passado sempre se relacione com o presente, garantindo a difusão do conhecimento e conservação da identidade caxiense.

Palavras-chave:patrimônio histórico, manifestações patrológicas, fachadas; IPHAN.

\begin{abstract}
The city of Caxias is located in the eastern region of Maranhão, in northeastern Brazil, being the fifth most populous municipality in the state, near $360 \mathrm{~km}$ from the capital São Luís. Historical, Caxias is marked by several long, glorious, bloody and poetic times, such as if it was a time tunnel. It is a historic city where memories permeate or daily lives of people in a relationship of major milestones that contributed to the construction of the history of Brazil. Despite its historical importance, as well as the fallen material that contributes to the understanding of the cultural identity of the city, there are few actions that intend its conservation, the same with the legal support provided for in article 216 of the federal constitution, decree law 25 / 1937 and state and local laws. In this sense, this work has as main objective to make a comparative study of the surveys of pathological manifestations incident in the facades of the main historical buildings located in the city center of Caxias, state of Maranhão. The methodology is based on technical histories by direct observation, aiming to record information about standardized planning, or what allows data to be processed. Besides indicating as manifestations, they were approached as possible causes and also techniques of restoration of the analyzed buildings, following the guidelines of the Institute of National Historical and Artistic Heritage (IPHAN). It is hoped that the results obtained may contribute to the preservation of the historical and cultural heritage of the municipality, allowing the past to always relate to the present, requesting the diffusion of knowledge and the conservation of the identity of the city.
\end{abstract}

Keywords: historical heritage, patrological manifestations, facades; IPHAN. 


\section{INSTRUÇÕES GERAIS}

A palavra patologia vem do grego phatos (doença) mais logos (estudo), no que resulta de um estudo da doença, termo comumente utilizado na medicina. Em outras palavras, estado patológico significa um estado doentio, anormalidade, mórbio ou falta de saúde. Nesse sentido, no contexo da engenharia civil, o termo é utilizado para expressar basicamente os defitos dos produtos decorrente da indústria da construção civil (SOUZA; RIPPER, 1998).

A preservação do patromônio cultural está intimamente ligada a ideia de desenvolvimento sustentável, sendo a utilização dos recursos presentes sem comprometer a habilidade das gerações futuras. Essa definição inicialmente foi desenvolvida em termo socioambiental, mas a dimensão cultural foi incorporada, inglobando os interesses da sociedade quanto ao patrimônio cultural material e imaterial (MEIRA, 2008).

É importante enfatizar que preservar o patrimônio histórico não busca perpetuar o passado, ou seja, não estereliza a criação e a inovação. A ideia de conservação contrapõe essa asserção, pois não preservar iria privar a sociedade de manter contato com suas raízes e das memórias que são essenciais no desenvolvimento da inovação. O passado em si pode chegar até nós de diversas maneiras (objetos, discussos, palavras, cheiros, documentos), isto é, esses vestígios conseguem ligar o presente com o passado, a ausência com a presença, transmitindo a sensação de permanecer, mesmo que de maneira fugaz, no passado.

No iníco do século XX eram raras as notícias relacionadas com a preservação do patrimônio histórico, sendo também difícil encontrar obras de restauração no Brasil. Com o passar do tempo, esse quadro mudou. Em todos os momentos, porém, a ideia de desenvolvimento desse tempo se deu através do reflexo que a sociedade fazia para os patrimônios históricos existentes (MEIRA, 2008).

Durante o desenvolimento desse tema, alguns momentos são importantes, como a criação do Serviço do Patrimônio Histórico e Artístico Nacional - SPHAN em 1937, a promulgação da lei nacional de arquiologia no ano de 1961, a criação do Centro Nacional de Referência Cultural - CNRC em 1975, programa das cidades históricas em 1977, a criação do programa Monumenta em 1999 e o registro de bens culturais de natureza imaterial no ano 2000.

Em sua versão latina, patrimonium está intimamente ligado ao significado de paterno e pátria, sendo um patrimônio produzido pelo homem em forma de uma cultura particular daquela sociedade. O patrimônio pode ser imaterial ou material, sendo este onde se enquadra a arquitetura, isto é, bens culturais materiais. O patrimônio cultural edificado possibilita a visibilidade do passado. A carta de veneza de 1964 exprime um conceito útil, onde "o sítio urbano ou rural que dá testemunho de uma civilização particular, de uma evolução significativa ou um acontecimento histórico" (ICOMOS, 2004).

A cidade de Caxias é situada na mesorregião leste Maranhense, no nordeste brasileiro, estando distante cerca de $360 \mathrm{~km}$ da capital São Luís. A complexidade cultural que permeia o município é estarrecedora ou, conforme descrito nas palavras de Pessoa (2007), “(...) não poderia conhecê-la, pois era labiríntica demais”. O valor história de Caxias é inegável, não apenas devido aos conterrâneos Coelho Neto e Gonçalves Dias, mas também por suas edificações e ruas se comumicarem a todo tempo com o passado, pois grandes marcos da história do Brasil ocorreram, parafraseando o poeta Gonçalves Dias, na terra "onde canta o sabia".

Um dos principais símbolos patrimoniais de Caxias é a antiga fábrica têxtil, hoje funcionando como centro cultural do município. Essa luxuosa edificação com traços arquitetônicos do final do século XIX representa o cotidiano fábril daquela época, onde operários que antes trabalhavam na agricultura, foram transformados em trabalhadores fabris. Juntamente com a antiga fábrica têxtil, uma série de edificações situadas no centro do município apresenta importante valor cultural (PESSOA, 2007).

Visando a conservação do patrimônio histórico do município de Caxias, esse trabalho apresenta o escopo principal de realizar um estudo comparativo dos levantamentos de manifestações patológicas incidentes nas fachadas dos principais prédios históricos localizado na região central, baseando-se, sobretudo, nos cadernos técnicos publicados pelo Instituto do Patrimônio Histórico e Artístico Nacional - IPHAN e pelo International Council of Monuments and Sites (ICOMOS). 


\section{PRINCIPAIS MANIFESTAÇÕES PATOLÍGICAS DOS REVESTIMENTOS ARGAMASSADOS}

\subsection{Fissuras e trincas}

O surgimento de fissuras e trincas em revestimentos argamassados podem estar associados a inúmeros fatores, sendo importante avaliá-los e identificá-los para determinar a correta terapia. Silva (2007) afirma que fissuras e trincas são causados pelos seguintes fatores:

○ Movimentações higroscópicas;

Movimentações térmicas;

Deformações das estruturas;

Recalque de fundação;

Retração de produtos à base do cimento;

Alterações químicas dos materiais.

Bauer (2008) também cita outro fator que gera fissuras e trincas, sendo a abertura de vãos, tais como janelas e portas, lembrando principalmente do princípio visto em resitência dos materiais denominado de Saint-Venant, onde ocorre uma concentração de tensão nas aberturas.

Nesse sentido, é possível classificar as fissuras e trincas em: mapeadas, retilíneas e localizadas ou formatos não classificados. Cada uma das categorias leva consigo os fenômenos citados por Silva (2007).

\subsubsection{Fissuras e trincas mapeadas}

As fissuras e trincas mapeadas está diretamente relacionada à retração do material, conforme descrito por Cincotto (1988), sendo dois principais fatores: retração do produto à base de cimento e a fadiga por expansão/retração higroscópica.

A retração é um fenômeno complexo e intríseco dos materiais da base do cimento. Pode ocorrer a saída (evaporação da água) ou a entrada (hidratação), fazendo a argamassa, na devida ordem, contrair e expandir. Tais movimentos geral tensões internas de tração que ultrapassam a capacidade de material. Carasek e Cascudo (2014) afirmam que mesmo após idedades avançadas, é possível verificar a variação volumétrica devido a higroscopia do ambiente.

Os principais fatores que causam a variação volumétrica na argamassa são: quantidade de cimento na mistura, composição química e finura do cimento, quantidade de água, condições em que a cura foi realizada, natureza dos agregados e sua granulometria (THOMAZ, 1992).

É importante diferenciar a retração plástica da retração por secagem. A primeira ocorre quando a argamassa ainda está no estado fresco, possuindo configuração mapeada. A retração por secagem, por sua vez, ocorre no estado endurecido, sendo relacionado à remoção de água da argamassa (adsorvida na pasta cimento) e também da retida por tensão capilar nos seus poros. A figura 01 ilustra o fenômeno de retração da argamassa quando ocorre a saída dos poros capilares.

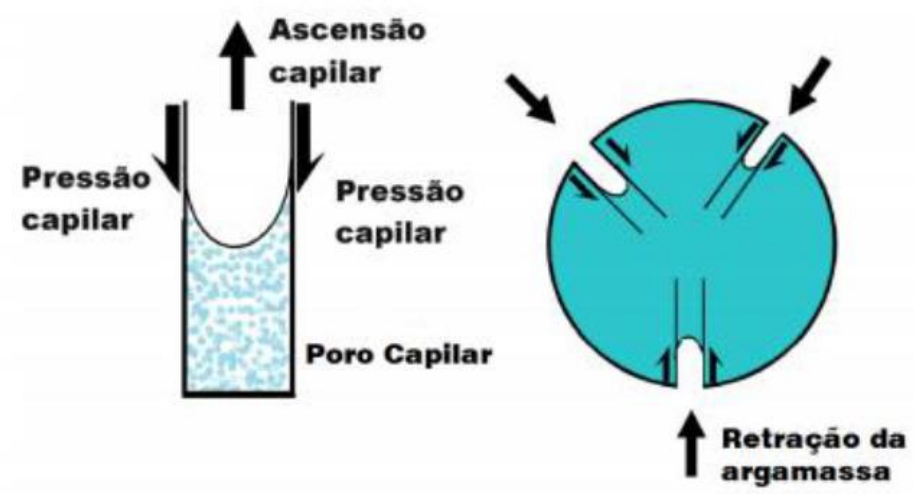

Figura 01: Fenômeno de retração da argamassa. Fonte: Carasek e Cascudo (2014). 


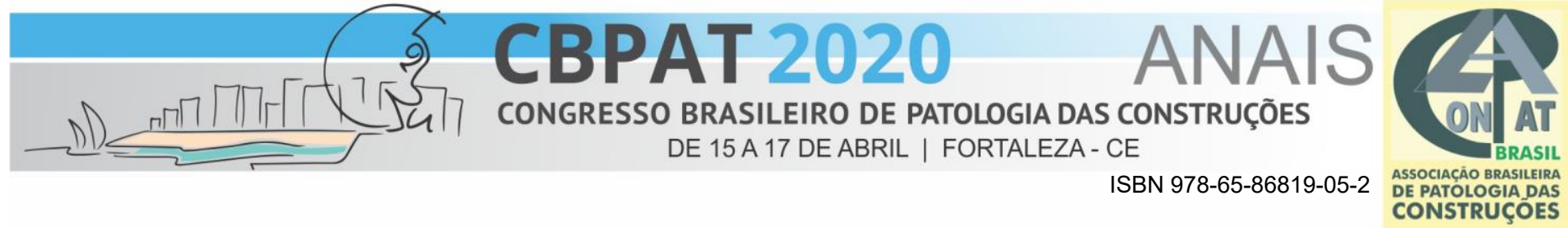

As figuras 02 e 03 ilustram esse tipo de fissura e trinca encontrado nas argamassas, realçando os mecanimos supracitados e sua identificação.

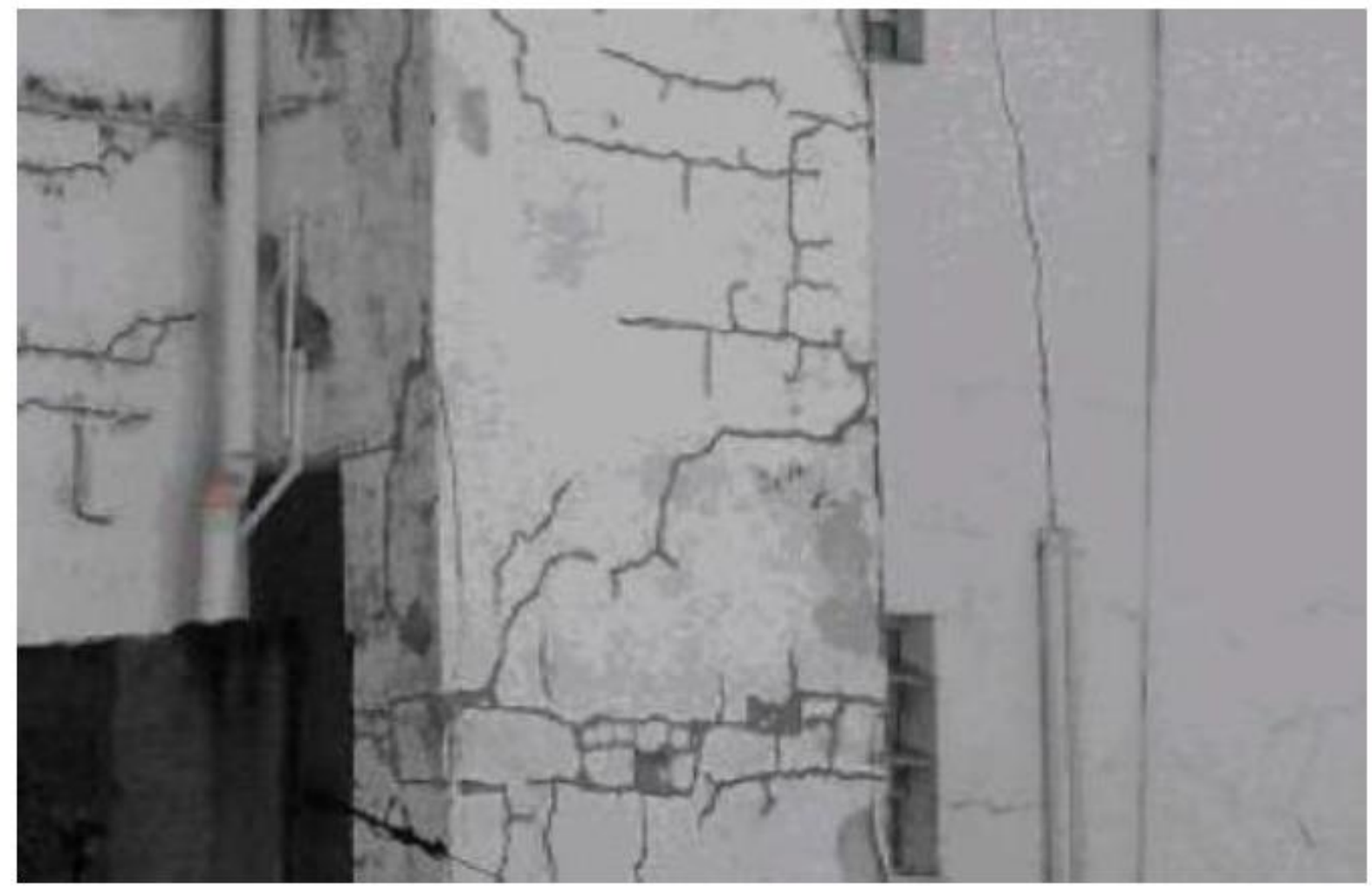

Figura 02: Retração por produtos à base de cimento. Fonte: Silva(2007).

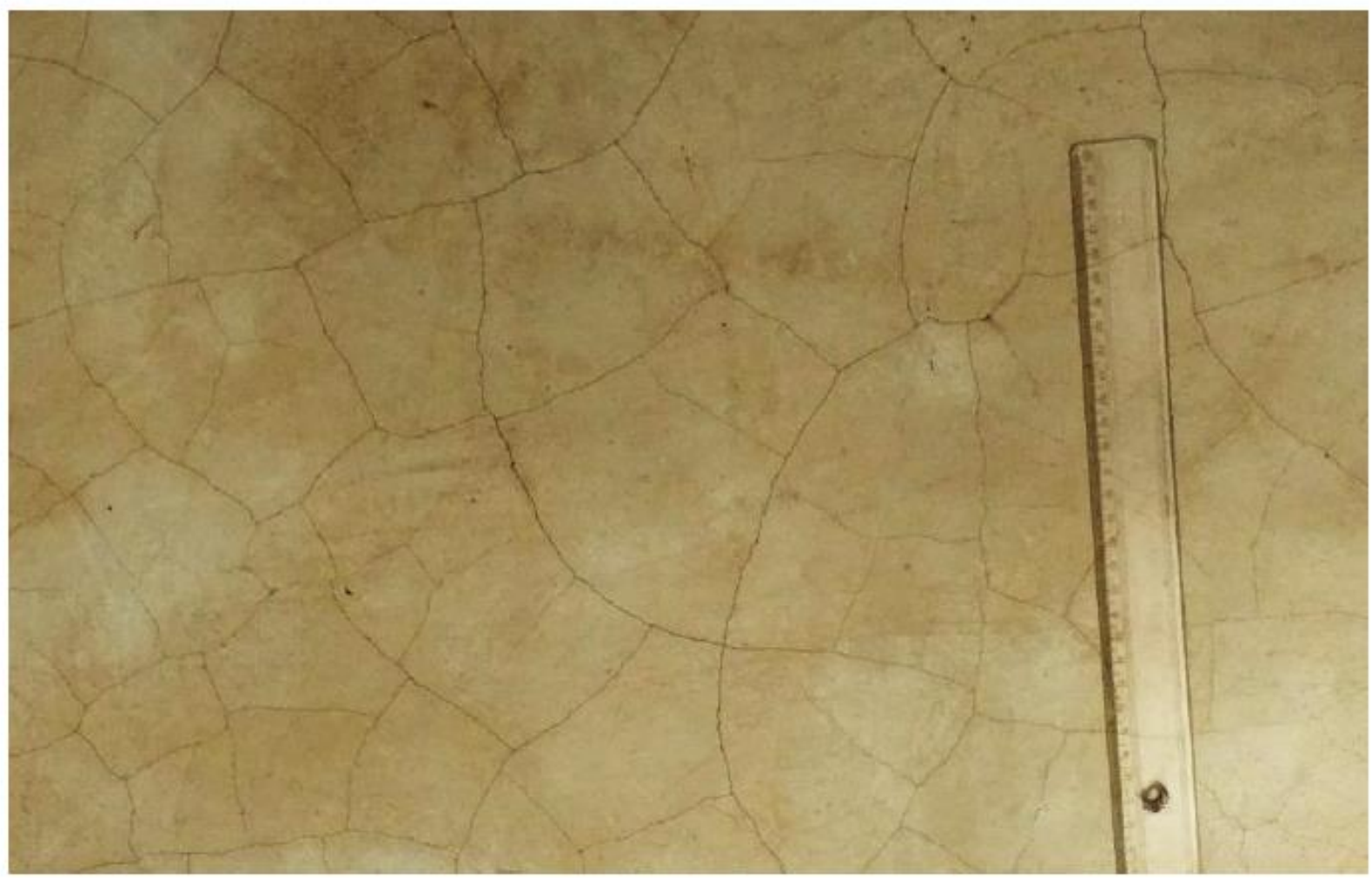

Figura 03: Fissuras mapeadas. Fonte: Silva (2007). 
Vale lembrar e a argamassa de revesimento é um meterial poroso, portanto submetido aos efeitos de capilaridade. Assim os poros absorvem a água por meio através da sucção devido ao fato do efeito de capilaridade. A expansão ocorre justamento quando a água do ambiente entra nos poros da argamassa. Quando essa água retorna ao ambiente através da evaporação, ocorre a retração da argamassa (THOMAZ, 1992).

Esse movimento de retração e expansão causa fadiga no material, ocorrendo as fissuras. A figura 04 ilustra a fadiga por expansão e contração higroscópica.

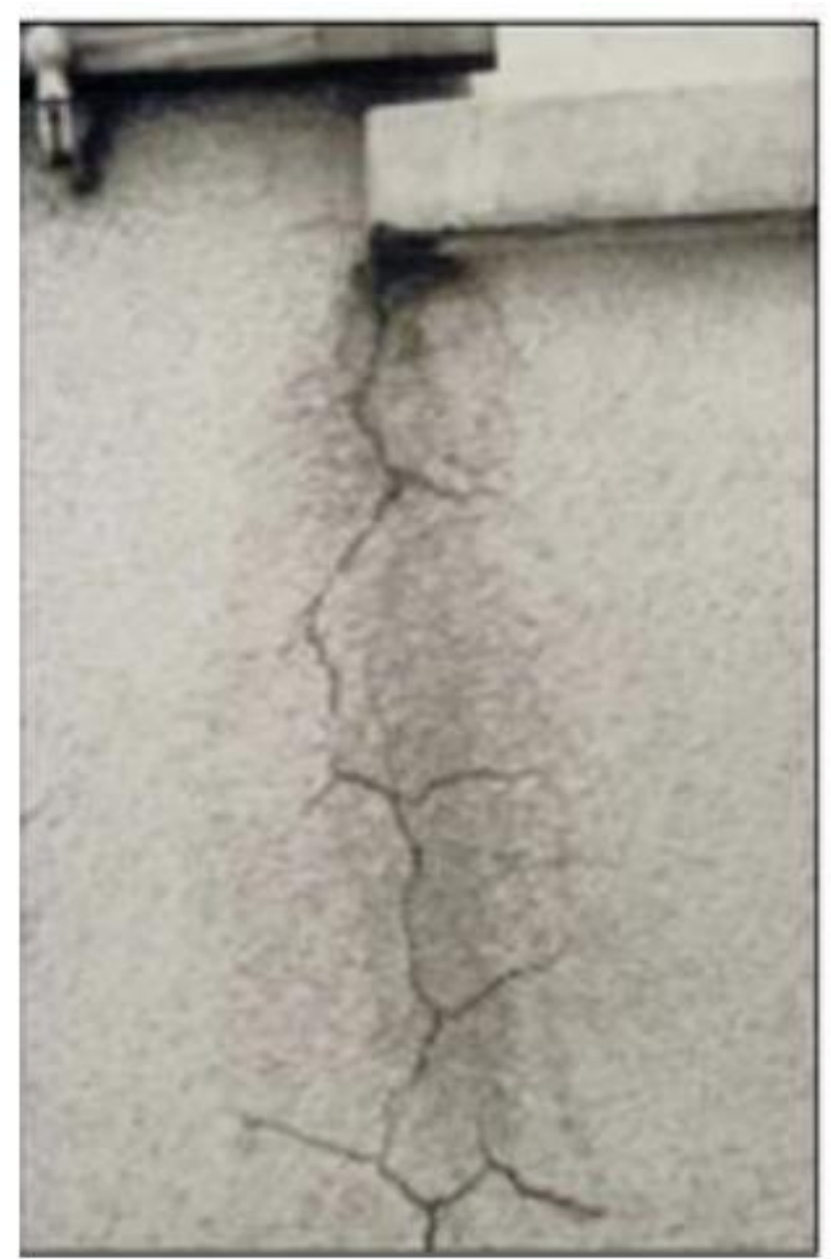

Figura 04: Fadiga por expansão e contração. Fonte: Silva (2007).

\subsubsection{Fissuras e trincas com tendências retilíneas e localizadas}

É um tipo de fissura fácil de identificar, pois ela é localizada e possui uma tendencia de se prolongar em uma direção, por isso chamada de retilínea.

A variação térmica é um dos motivos desse tipo de fissura, sendo vinculada a dois fatores: propriedades físicas do material e a intensidade da variação térmica. Isso ocasiona movimentações diferenciadas, pois são diferentes materiais que estão em movimentação, ocasionando tensões (THOMAZ, 1992).

Silva (2007) deixou claro que as movimentaçóes diferenciadas podem ser ocasioada pelos seguintes fatores:

- Coeficiente de dilatação térmica distindo;

Exposição dos elementos a diferentes solicitações térmicas;

- Gradiente de temperatura (variação da temperatura ao longo do mesmo componente). 
A figura 05 ilustra uma fissura entre a interface alvenaria e estrutura devido justamente às movimentações térmicas, sabendo que o concreto e a argamassa se movimentam diferente devido seus coeficientes de dilatação, ocorre tensões na ligação de ambos.

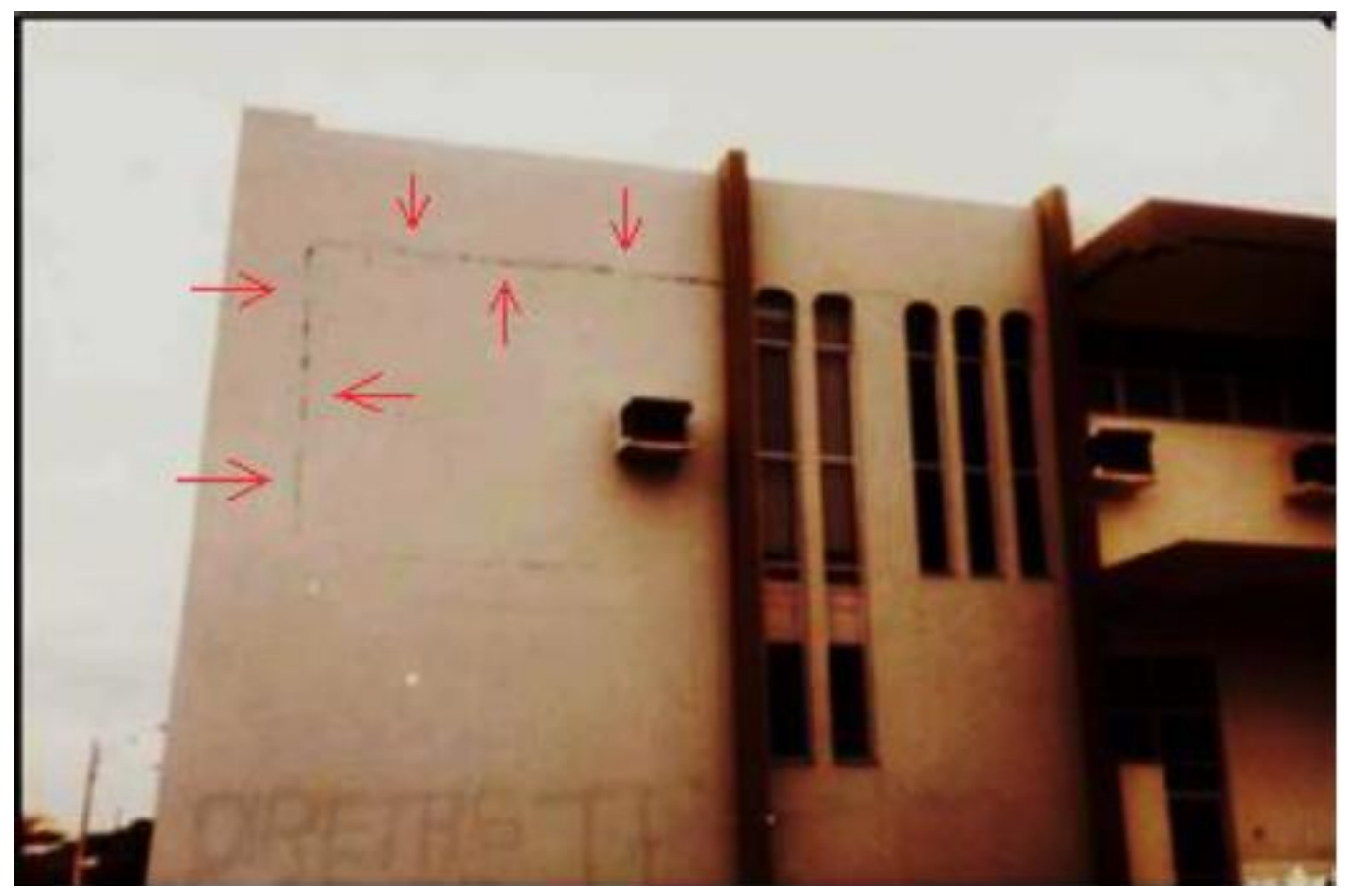

Figura 05: Fissuras na interface alvenaria e estrutura. Fonte: Thomaz (1992).

Outro tipo de fissuras localizadas e retilínea ocorre devido a deformação das estruturas. Silva (2007) afirma que as flechas excessivas em lajes e vigas podem desenvolver esse tipo de fissura.

A figura 06 ilustra fissuras devido ao cisalhamento nos cantos superiores e inferiores que ocorre na alvenaria quando a viga de apoio apresenta flecha excessiva.

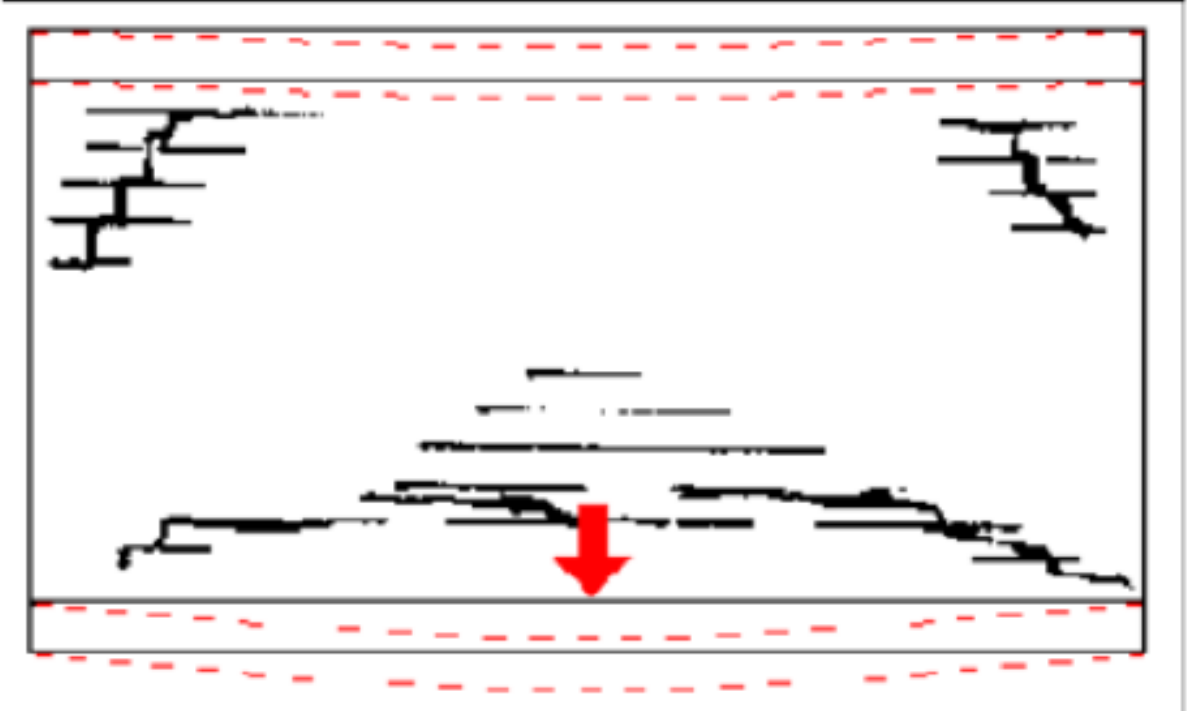

Figura 06: Fissura decorrente de flecha excessiva no apoio da alvenaria. Fonte: Thomaz (1992).

A figura 07 ilustra o esmagamento da alvenaria quando a viga superior se deforma mais que a inferior. Assim ocorre fissuras de cisalhamento nos cantos superiores, sendo as fissuras horizontais e verticais. 

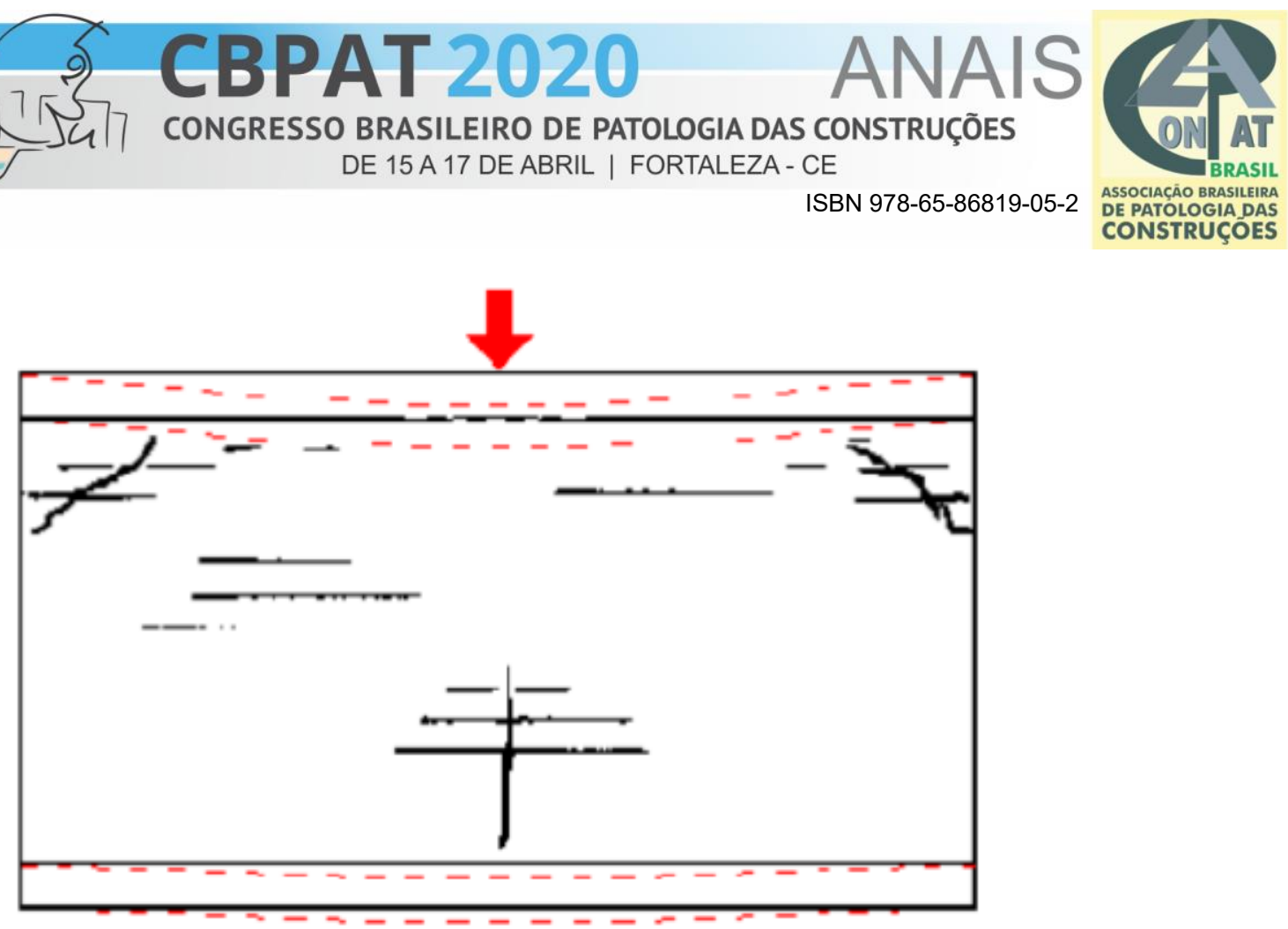

Figura 07: Fissura decorrente de flecha excessiva na viga superior. Fonte: Thomaz (1992).

Outro tipo de fissuras localizadas ocorre devido os recalques das fundações, sendo relacionado à capacidade de carga e deformabilidade dos solos. Alguns fatores podem ser citados, conforme Thomaz (1992): tipo de solo, influência das edificações vizinhas, disposição do lençol freático, intensidade de carga, tipo de fundação, entre outros.

Esse tipo de fissura é geralmente inclinadas (próximas de $45^{\circ}$ ), apresentando esmagamento localizado devido às tensões cisalhantes. As figuras 08 e 09 ilustram duas causas como exemplo.

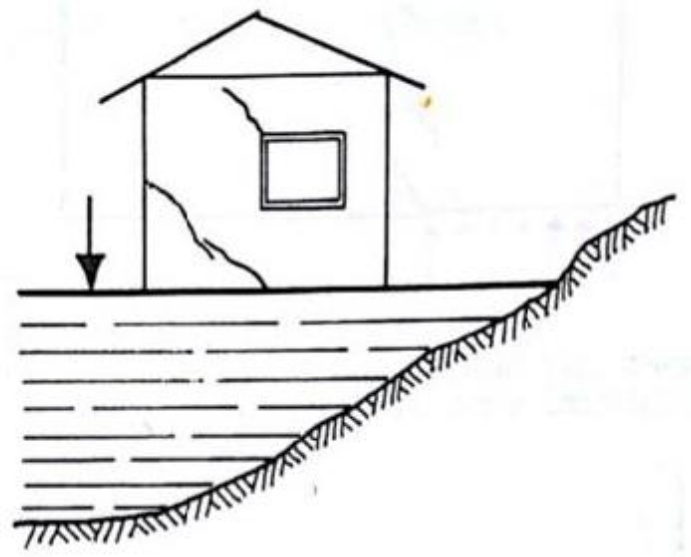

Figura 08: Recalque devido consolidação de aterro argiloso. Fonte: Thomaz (1992).

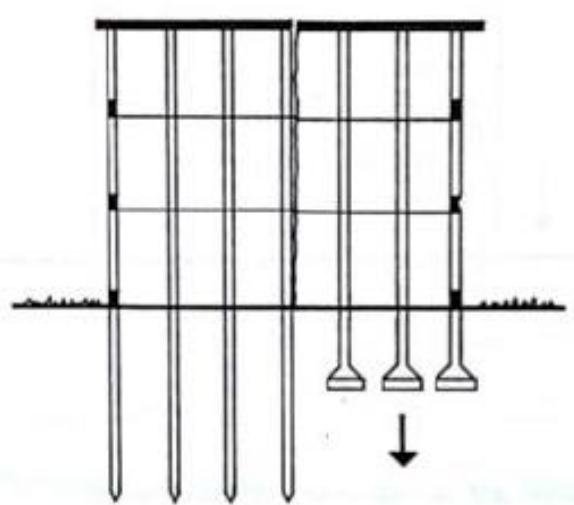

Figura 09: Recalque diferenciado em sistemas distintos de fundação. Fonte: Thomaz (1992). 


\section{CBPAT 2020 \\ CONGRESSO BRASILEIRO DE PATOLOGIA DAS CONSTRUÇÕES \\ DE 15 A 17 DE ABRIL | FORTALEZA - CE}

A execução de portas e janelas, isto é, abertura nas alvenarias, ocorre concetração de tensão, conform princípio de Saint-Venant. As vergas e contravergas desempenham função de neutralizar a concentração de tensões nos cantos de portas e janelas. Se esses elementos não existirem, ocorrerá fissuração, conforme figura 10.

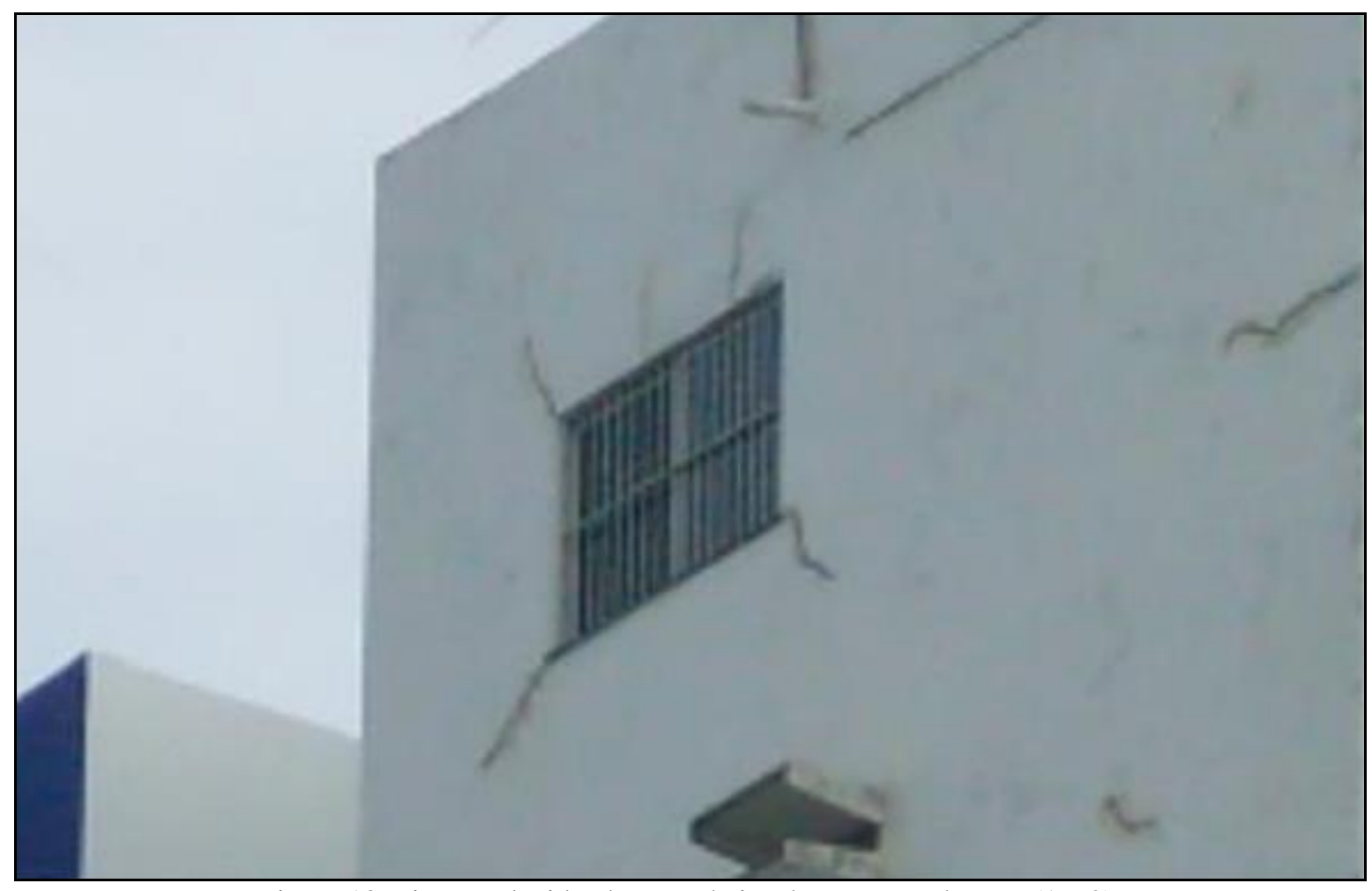

Figura 10: Fissuras devido abertura de janelas. Fonte: Thomaz (1992).

\subsubsection{Fissuras de outros formatos}

Diversas variações de fissuras e trincas não podem ser classificadas nos itens anteriores. Algumas fissuras e trincas apresentam formas generalizadas, conforme a figura 11.

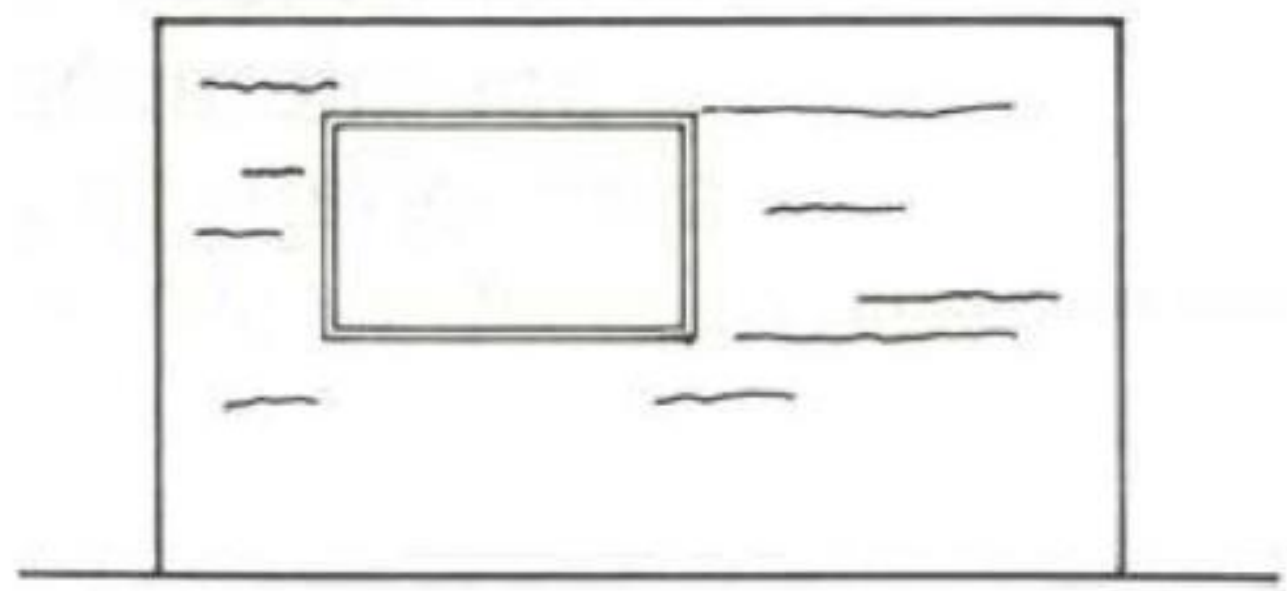

Figura 11: Fissuras horizontais provocadas pela expansão da argamassa de assentamento. Fonte: Thomaz (1992).

Porém, para os fins desta revisão (de iniciação aos estudos da patologia de revestimentos em argamassa), o aprofundamento desta seção se faz desnecessário, uma vez que as variações de fissuras mais frequentemente encontradas na bibliografia consultada já foram devidamente apresentados nos tópicos anteriores. 


\section{METODOLOGIA}

A fim de utilizar termos apropriados conforme as teorias de pesquisas, os materiais e métodos utilizados para alcançar os objetivos propostos nesse estudo se baseiam, conforme definições de Lakatos (2003), nas metodologias denominadas documentação indireta (pesquisa bibliográfica e documental) e documentação direta (pesquisa em campo).

Seguindo as recomendações do Instituto do Patrimônio Histórico e Artístico Nacional - IPHAN e do international Council on Monuments and Sites - ICOMOS, criou-se uma metodologia baseada, essencialmente, pelo fato de ser nacional, nas informações do IPHAN (2005) e complementadas pelas diretrizes propostas em ICOMOS (2012). A figura 12 ilustra a síntese dos métodos que serão utilizados.

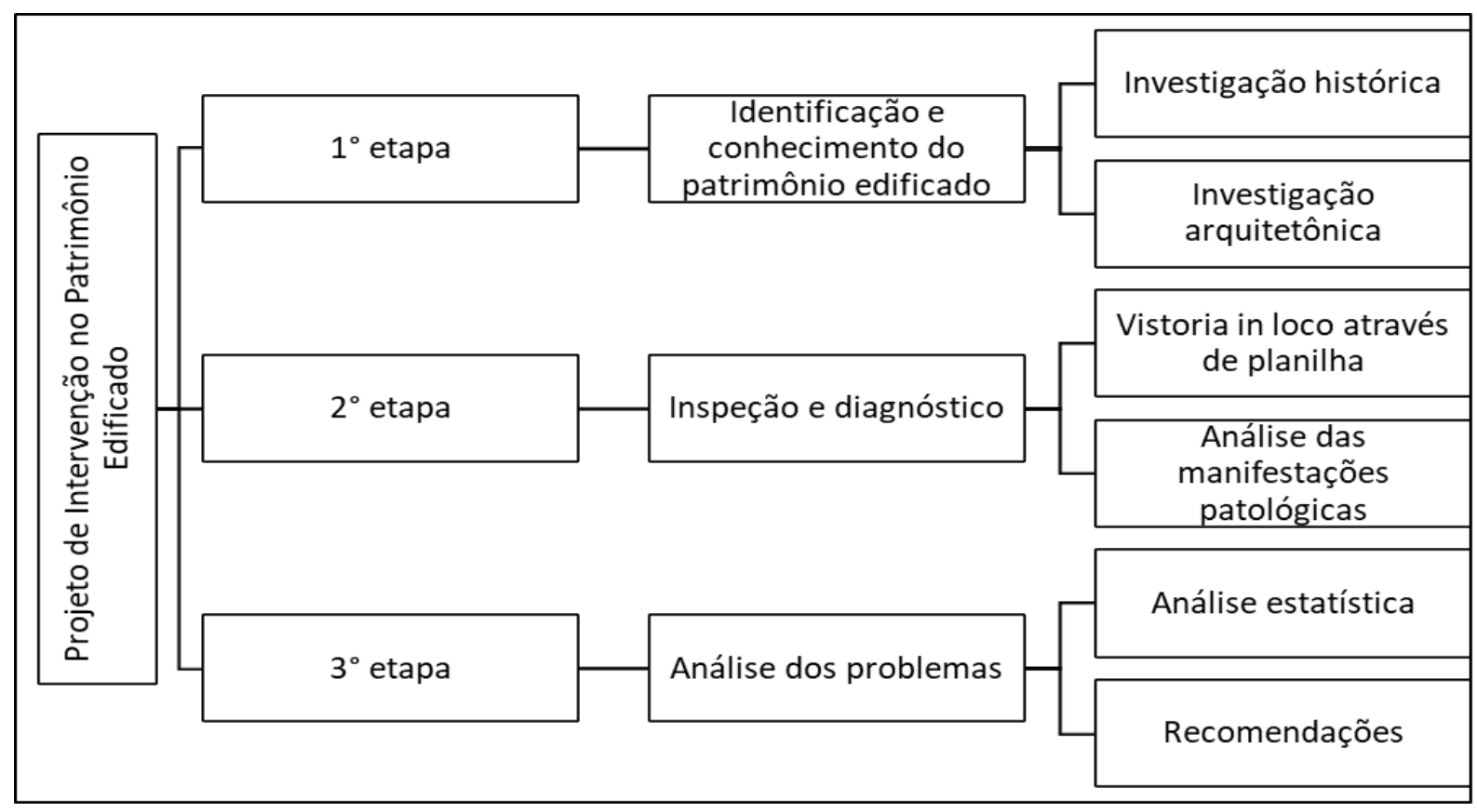

Figura 12: Metodologia de análise.

Durante a segunda etapa, utilizou-se o modelo de planilha representada na figura 13, mantendo uma padronização na coleta de informações e possibilidade de analisar todas as manifestações patológicas.

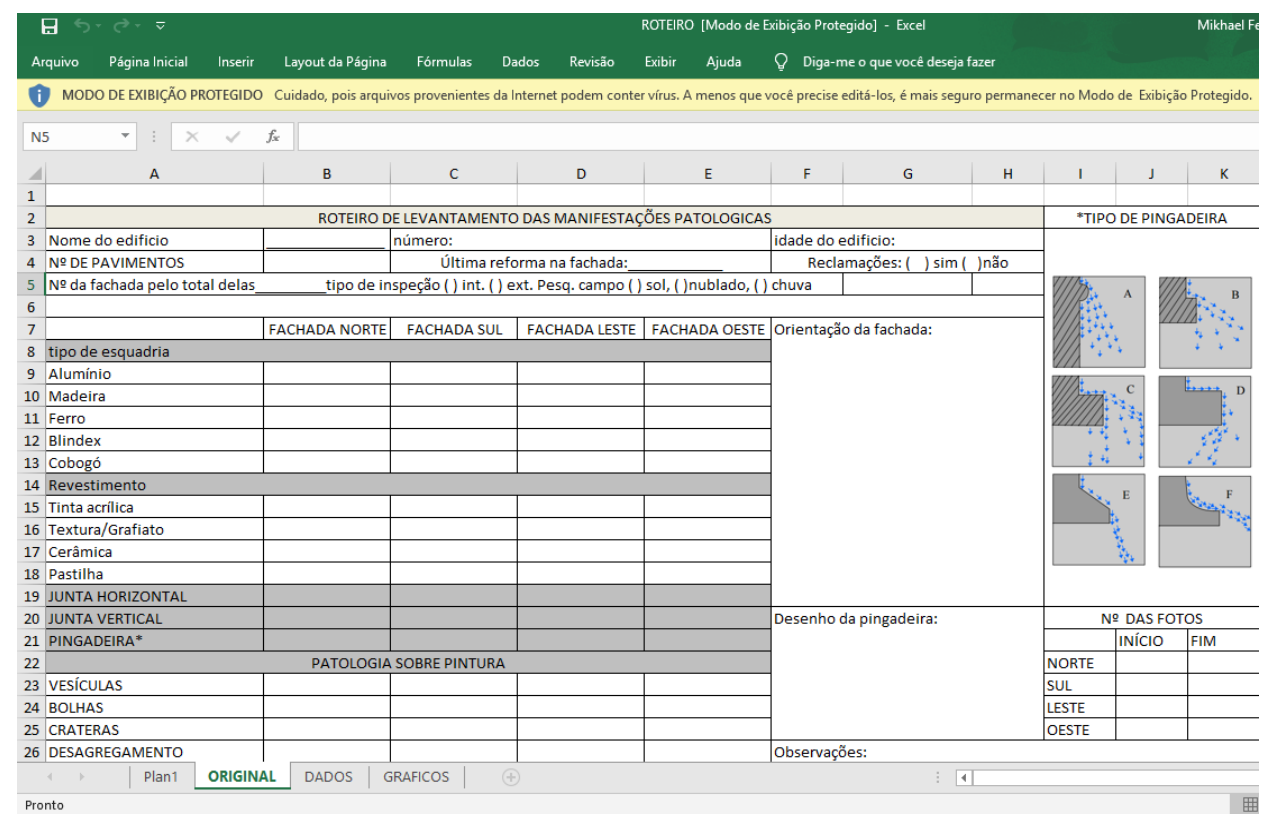

Figura 13: Planilha utilizada nas vistorias. 


\section{RESULTADOS}

As vistorias foram realizadas com inspeção externa com estado do campo ensolarado, valendo salientar que no município encontra-se em um período chuvoso.

Dentre as manifestações patológicas encontradas, analisou-se os seguintes itens:

- Tipo de esquadria (alumínio, madeira, cobogó, blindex ou ferro);

- Revestimento (tinta acrílica, textura/grafiato, cerâmica e pastilha);

- Patologia sobre pintura (vesículas, bolhas, destacamento, diferença de tonalidade, eflorescência, fissuração, manha embaixo da janela e manha na platibanda);

- Patologia sobre a cerâmica (destacamento, eflorescência, fissuração, mancha embaixo da janela, platibanda e quebra de peças cerâmicas).

A figura 14 ilustra a incidência de manifestações patológicas relacionada às fachadas executadas com pintura acrílica, realçando a incidência de cada uma com relação ao total.

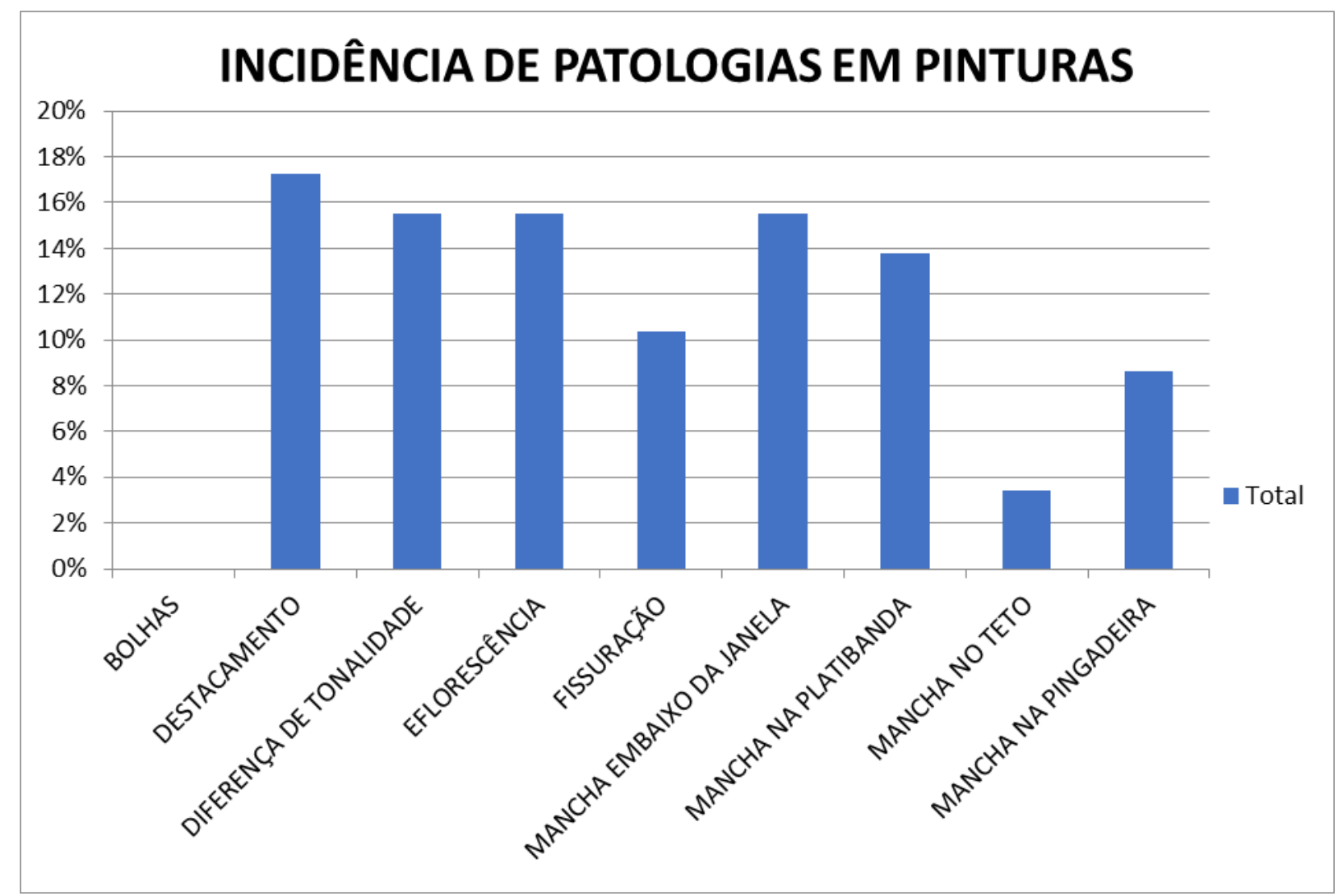

Figura 14: Incidência de manifestações patológicas em fachadas históricas executadas com pintura acrílica.

Como se pode observar, $17 \%$ das incidências está relacionado ao destacamento, isto é, remoção da camada de pintura acrílica. Esse fato está aliado às condições climáticas da região (chuva e temperatura), principalmente o gradiente térmico durante o dia. Juntamente, em porcentagem bem próximas, encontra-se diferença de tonalidade (16\%), eflorescência (16\%) e mancha em baixo da janela (16\%) com incidências praticamente conjuntas. A umidade, principalmente durante a época em que as vistorias foram realizadas, afeta muito os materiais presentes, aliado a uma escassez de manutenção nas fachadas históricas.

As pingadeiras encontradas foram do tipo ilustrado na figura 10, possuindo péssima eficiência, o que justifica as manifestações patológicas existentes como mancha na pingadeira (9\%) e mancha na platibanda (14\%). É importante realçar que todas as edificações históricas, não somente em pintura acrílica, possuíam pingadeira tipo $\mathrm{D}$, conforme figura 15, isso devido à arquitetura portuguesa que influenciou muito o município de Caxias. O contexto histórico de Caxias é muito bem explicado em Pessoa (2008). 

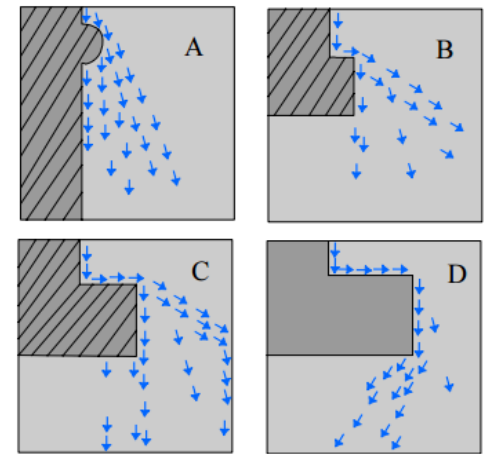

Figura 15: Modelo de pingadeiras para vistorias das fachadas históricas.

As figuras 16 e 17 ilustram duas fachadas históricas executadas em pintura acrílica, realçando as manifestações patológicas, bem como a arquitetura portuguesa influente no município.

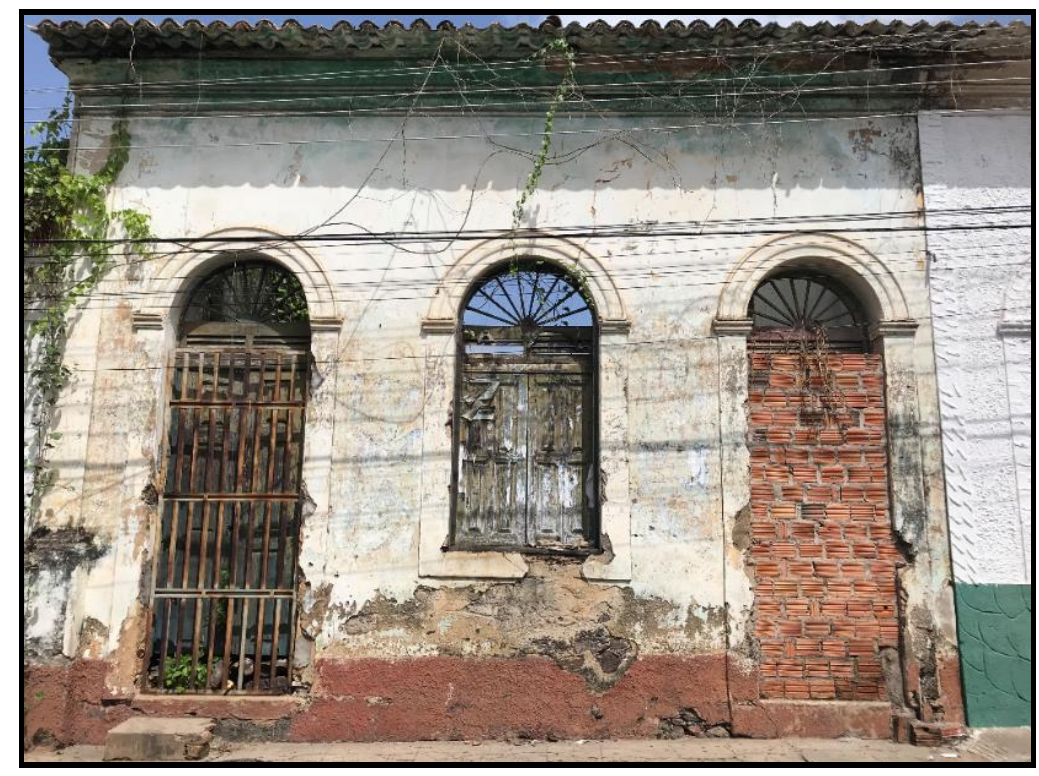

Figura 16: Estado precário de fachada histórica.

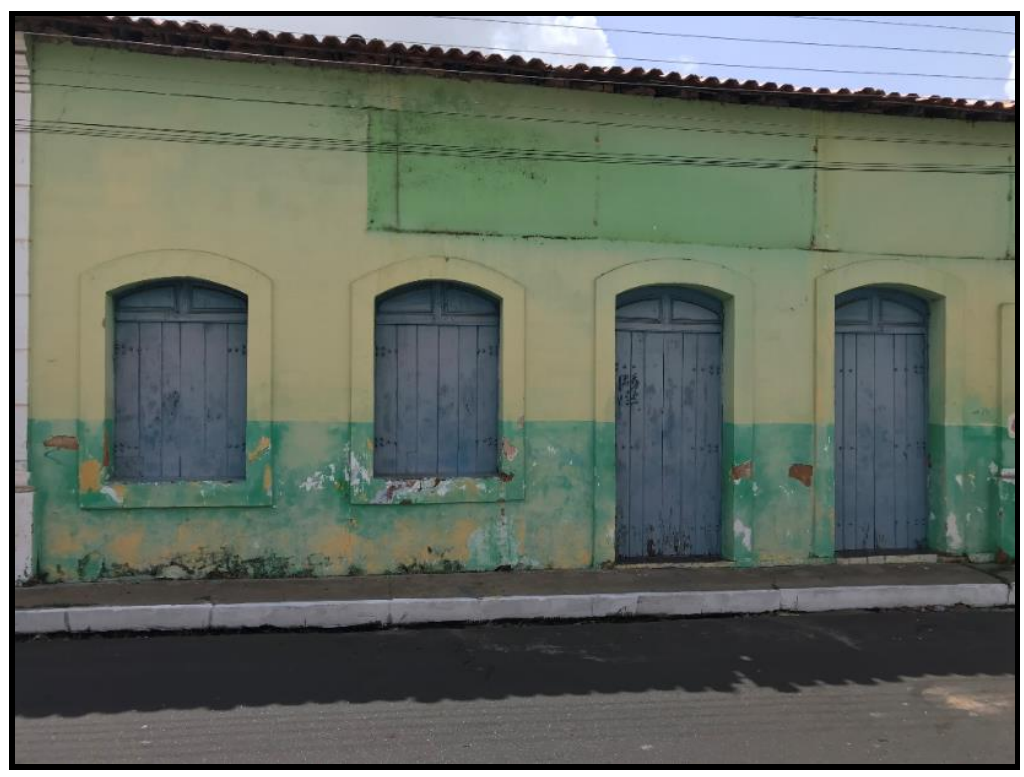

Figura 17: Fachada histórica e realce das manifestações patológicas encontradas. 


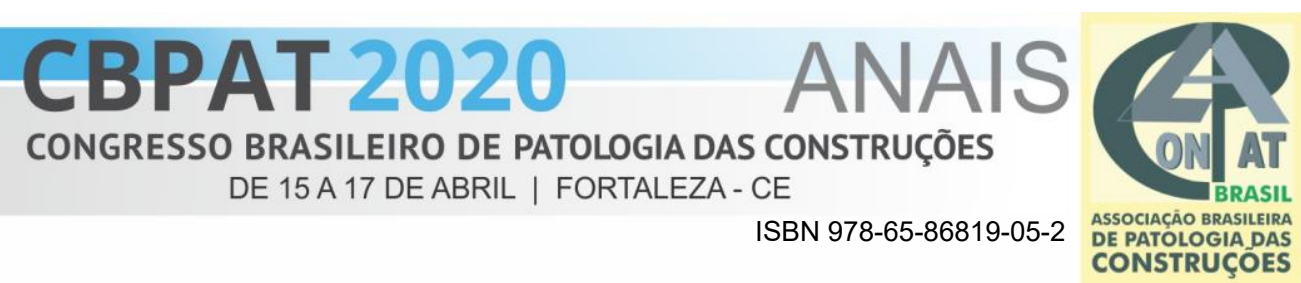

É importante realçar que dentre as fachadas encontradas, uma apresenta-se em estado crítico, com sua estrutura fora do prumo, sendo possível o acidente estrutural, conforme ilustrado nas figuras 18 e 19.

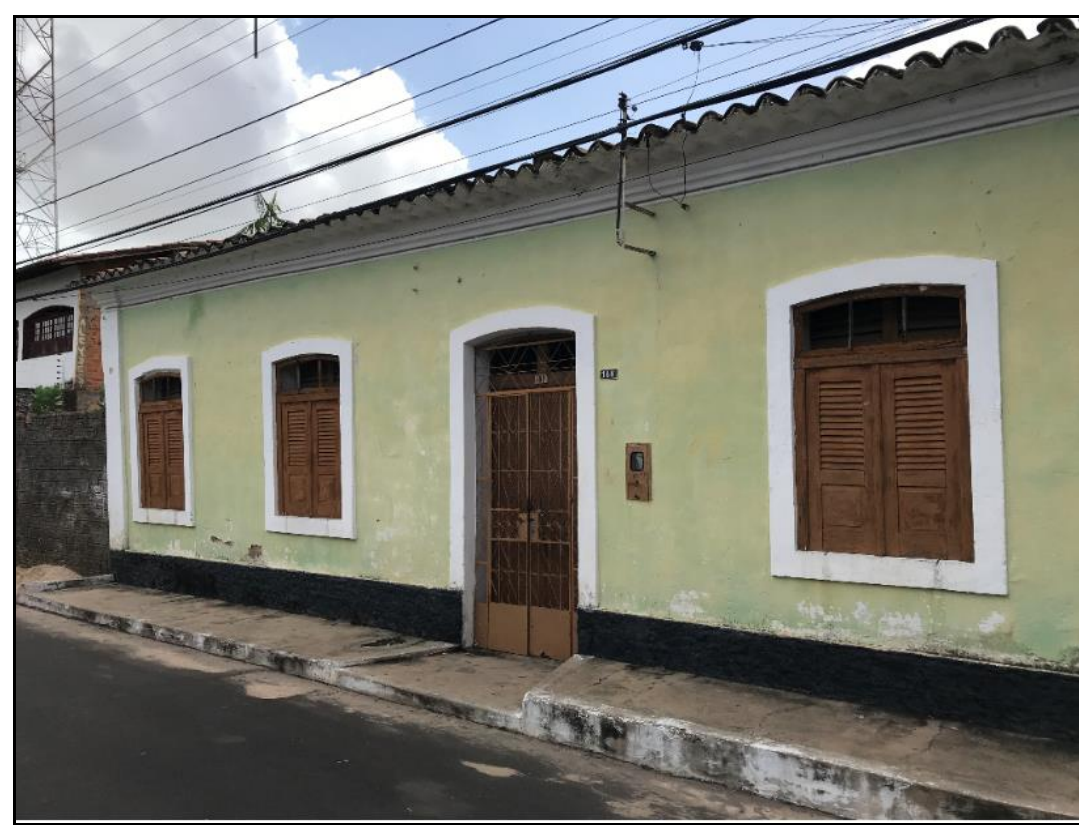

Figuras 18: Fachada histórica em estado crítico.

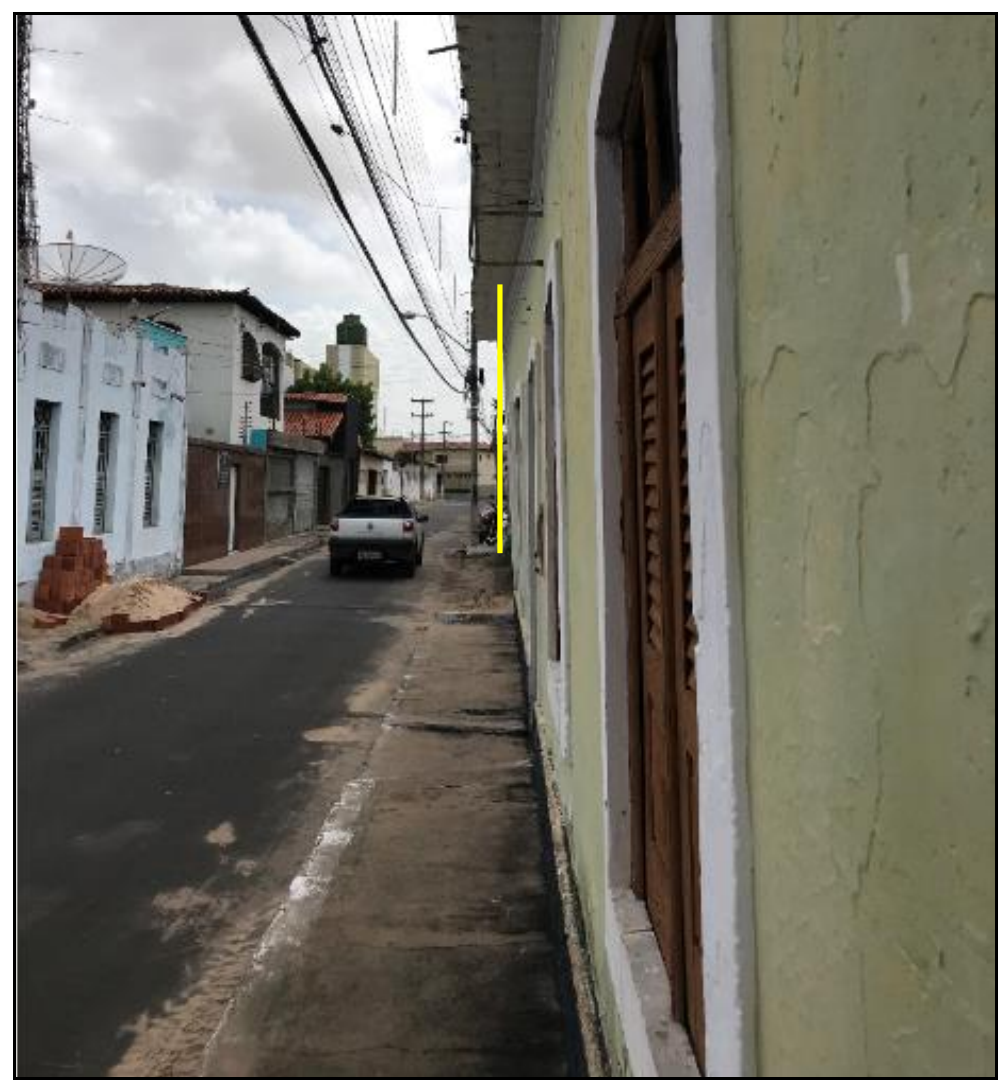

Figuras 19: Vista da notória deformação da vedação da edificação.

A figura 19 realça a inclinação existente, embora não mensurada, vista na vedação da edificação em estudo. Essa manifestação patológica é preocupante, principalmente pelo fato da via ser estreita. Tal fachada exige recuperação imediata para evitar problemas maiores. 
A figura 20 ilustra a incidência de manifestações patológicas relacionada às fachadas executadas com cerâmica, realçando a incidência de cada uma com relação ao total.

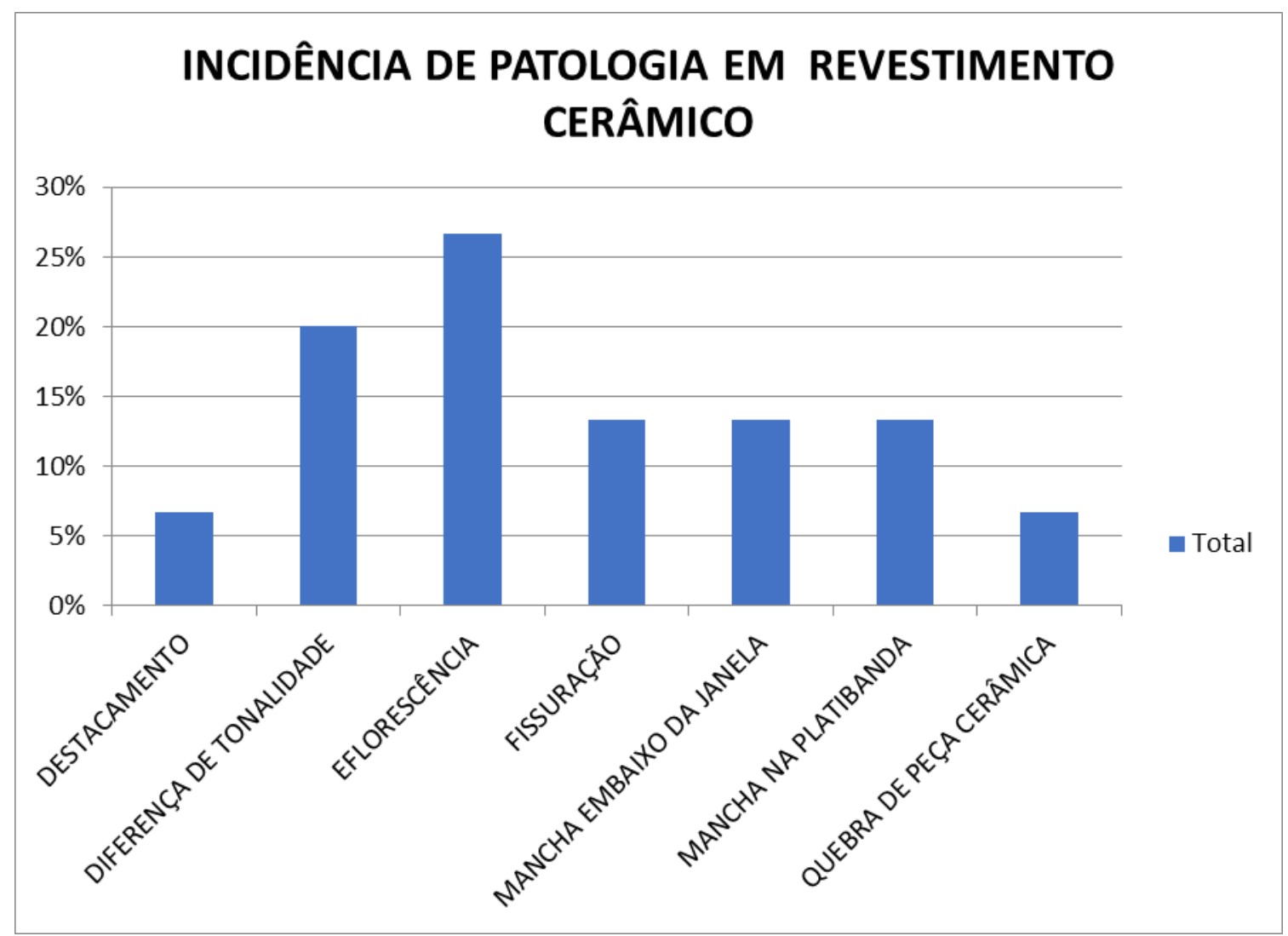

Figura 20: Manifestações patológicas encontradas em fachadas executadas com cerâmica.

Conforme figura 21, a maior incidência de manifestações patológicas em fachadas executadas com cerâmica está concentrada na eflorescência, com $27 \%$. Isso justifica-se principalmente com a variação de umidade e gradiente térmico que faz com o que o processo da eflorescência ocorra, semelhantemente às fachadas executadas em tinta acrílica. A foto 10 ilustra um exemplo de fachada com eflorescência bem como o destacamento das cerâmicas.

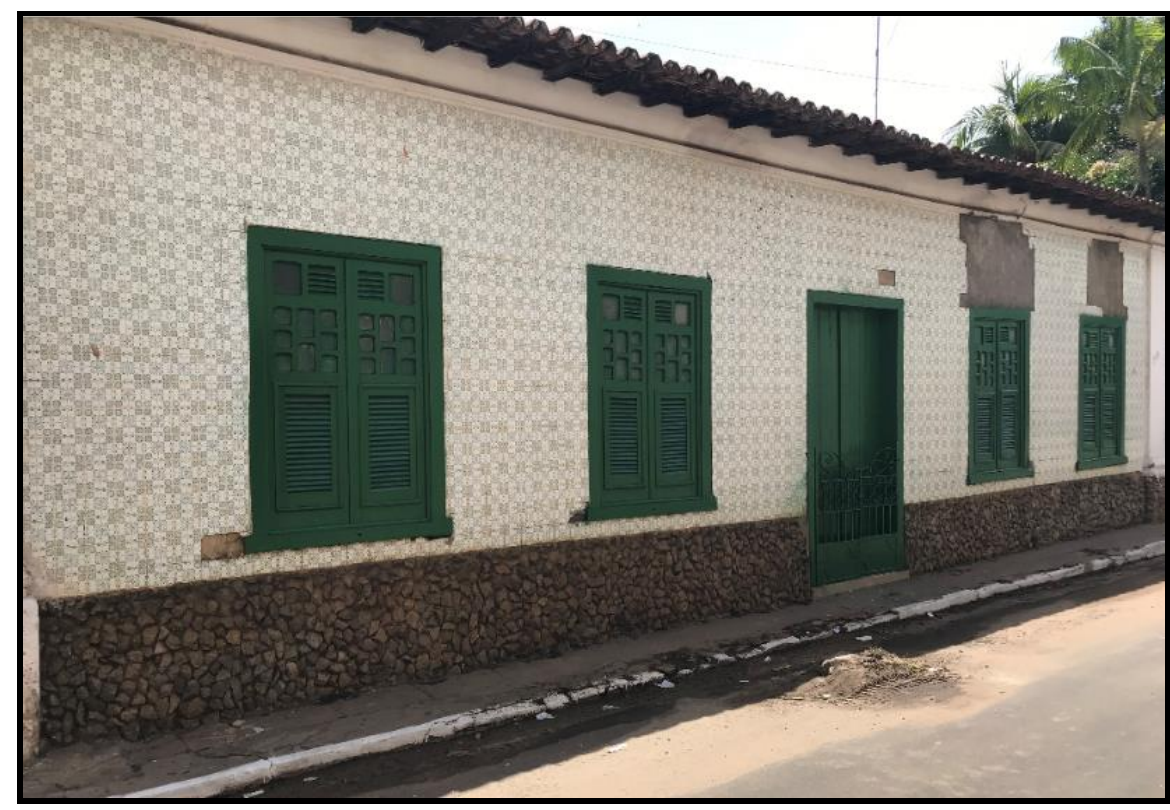

Figura 21: Fachada história no município de Caxias - MA. 
Em segundo plano está a diferença de tonalidade (20\%), muito ligada a existência de efluência nas fachadas vistoriadas. É importante realçar que a maioria das fachadas vistoriadas sem ao menos uma manutenção executada durante sua vida útil, apresentada estados deploráveis de acabamento.

As figuras 22 e 23 ilustram o gráfico de incidência de manifestações patológicas executadas, na devida ordem, em tinta acrílica e peças cerâmicas de acordo com a orientação geográfica, fachada norte (FN), fachada sul (FS), fachada leste (FL) e fachada oeste (FO).

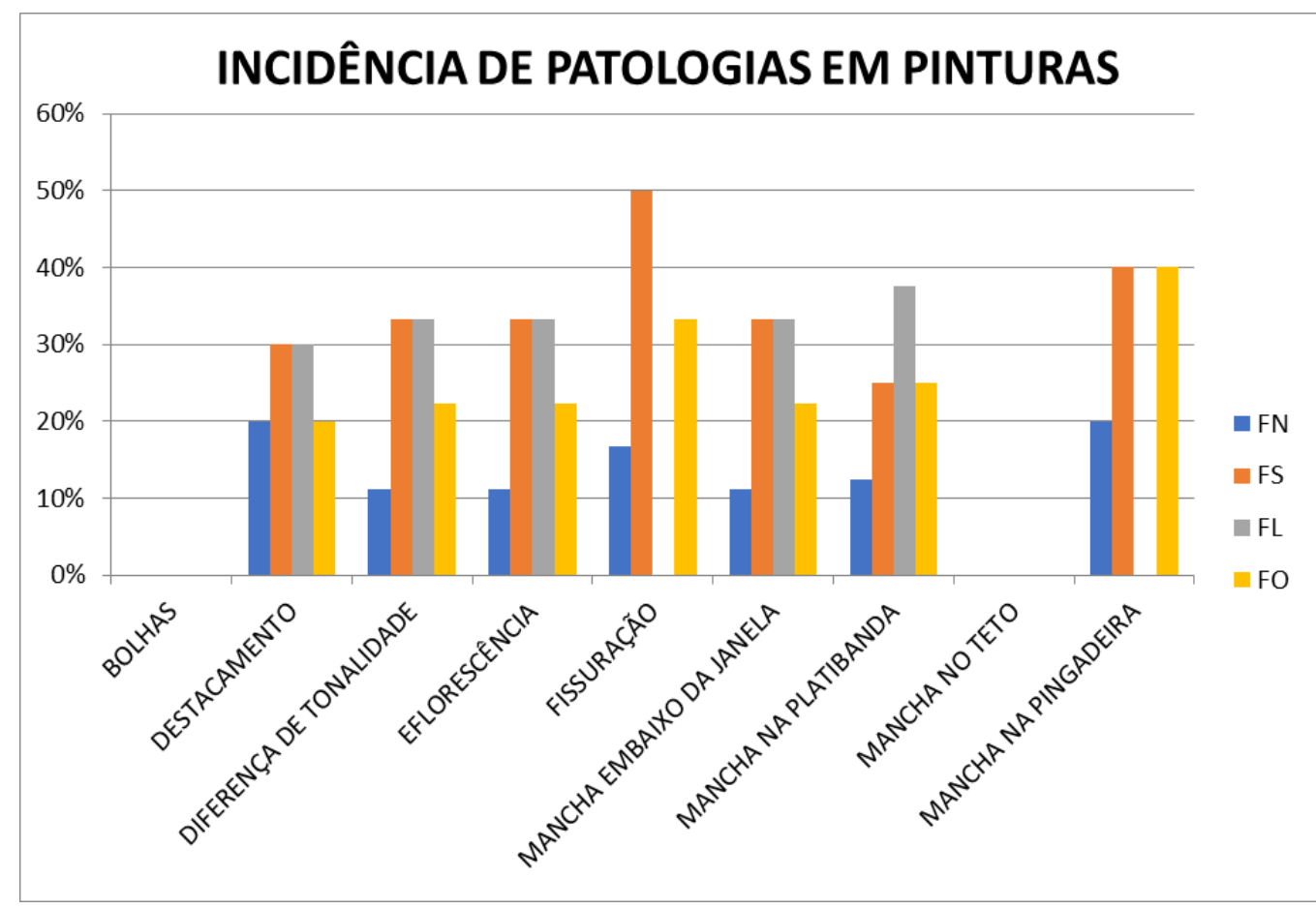

Figura 22: Manifestações patológicas em fachadas executadas em tinta acrílica.

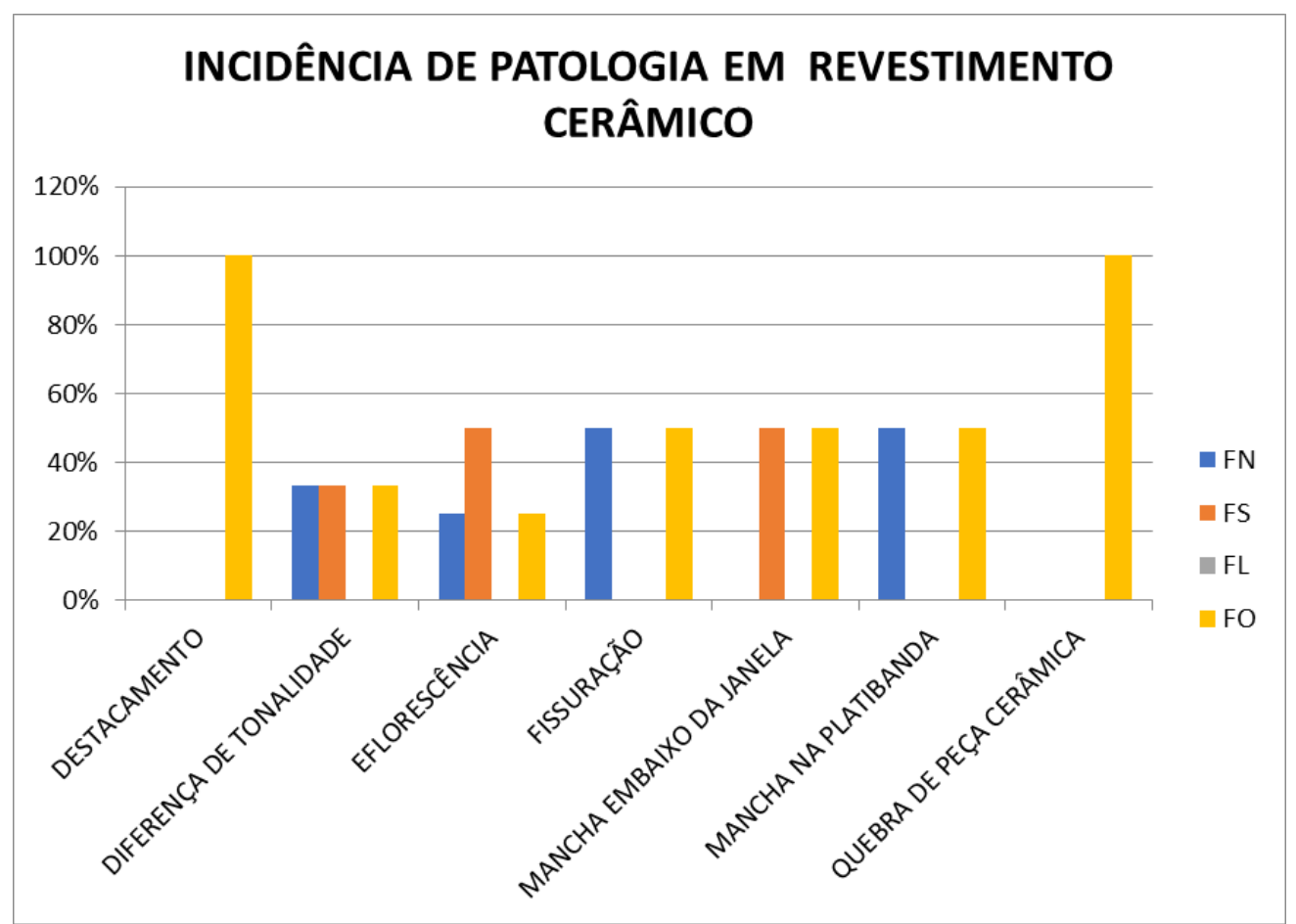

Figura 23: Manifestações patológicas em fachadas executadas em cerâmica. 


\section{CONCLUSÕES}

Diante de todo o exposto, embora algumas áreas críticas encontradas conforme demonstrado no item anterior, a recuperação das fachadas preservando suas características originais é possível. As intervenções mais importantes devem ser realizadas o mais rápido possível, principalmente nos locais que propiciam riscos aos usuários.

Vale ressaltar que nesse trabalho não se verificou as manifestações patológicas nas esquadrias das fachadas, pois muitas delas já foram alteradas, mesmo sendo um patrimônio tombado. Nesse sentindo, a fim de evitar possíveis conclusões diferentes da realidade, optou-se por não analisar as esquadrias.

Esse trabalho possui um viés muito importante para conservação de patrimônio histórico, principalmente no município de Caxias, estado do Maranhão. As conclusões desse trabalho podem ser estendidas para cidades circunvizinhas, devido a semelhança de manifestações patológicas em fachadas.

Espera-se, também, que esse trabalho impulsione os órgãos competentes a realizar intervenções para preservar os patrimônios históricos, lembrando que este é uma interligação do presente com o passado. Um dos fatores que culminou nas manifestações patológicas foi, sem dúvida, a falta de manutenção das fachadas existentes, que é um problema corrente no Brasil. Deve-se, portanto, ser previsto um plano de manutenção para todo patrimônio histórico edificado, não somente nas fachadas, mas na edificação como um todo. Vale ressaltar que Caxias, estado do Maranhão, é uma cidade cujo todo o centro é histórico e muitos patrimônios edificados estão necessitando de intervenção.

\section{REFERÊNCIAS}

BAUER, L. A. F. Materiais de Construção.5.ed. Rio de Janeiro: Livros Técnicos e Científicos Editora, 2008. Volume 2.

CARASEK, H.; CASCUDO, O. Consultoria para diagnóstico e terapia de pisossobre mantas acústicas. Núcleo de Tecnologia das Argamassas e Revestimentos -NUTEA -EECA -UFG. Relatório Técnico. Agosto de 2014. 23p.

ICOMOS. Carta de Veneza. In: Cury, I. Cartas patrimoniais. Rio de Janeiro: IPHAN, p.91-95, 2004, p.92.

LAKATOS, E. M. Fundamentos de metodologia científica. $5^{a}$ edição. São Paulo: Atlas. 2003. 310p.

MEIRA, A. L. G. O patrimônio histórico e artístico nacional no Rio Grande do Sul no século XX: atribuição de valores e critérios de intervenção. Tese (doutorado em Planejamento Urbano e Regional) - Universidade Federal do Rio Grande do Sul. 2008. 483p.

PESSOA, J. M. Entre a tradição e a modernidade: a belle époque caxiense, práticas fabris, reordenamento urbano e padrões culturais no final do século XIX. 2007.

PESSOA, J. M. Entre a tradição e a modernidade: a belle époque caxiense (práticas fabris, reodernamento urbano e padrões culturais no final do século XIX). Dissertação (mestrado em história) - Universidade Federal do Piaui. 2007. $144 \mathrm{p}$.

SILVA, A. F. Manifestações patológicas em fachadas com revestimentos argamassados:Estudo de caso em edifícios em Florianópolis.Dissertação (Mestrado).Universidade Federal de Santa Catarina, Florianópolis, 2007.

SOUZA, V. C. M.; RIPPER, T. Patologia, recuperação e reforço de estruturas de concreto. São Paulo: Pini, 1998.

THOMAZ, E. Trincas em edifícios:causas, prevenção e recuperação. São Paulo, Ed. PINI,1992. 